\title{
Moderating Role of Perceived Justice in Organizational Citizenship Behavior (Evidence from Iran)
}

\author{
Mohammad Hosseinkhani ${ }^{1}$ \& Qurban Giyaove ${ }^{1}$ \\ ${ }^{1}$ Faculty of Social science, University Academy Of Tajikistan, Dushanbe, Tajikistan \\ Correspondence: Mohammad Hosseinkhani, Faculty of Social science, University Academy Of Tajikistan, \\ Dushanbe, Tajikistan. E-mail: 86hossein@gmail.com
}

Received: June 14, 2015 Accepted: July 8, $2015 \quad$ Online Published: July 30, 2015

doi:10.5539/res.v7n11p285 URL: http://dx.doi.org/10.5539/res.v7n11p285

\begin{abstract}
Background and aim: Satisfaction of employees plays an important role in the quality of their service providing which in turn leads to the promotion of organizational level as well as fulfillment of organization goals and establishment of justice. The perception of justice by employees is one of the factors affecting their satisfaction. In this regard, the present study aims to determine the relationship between social justice and organizational citizenship behavior (OCB) in some job groups of Metro Operation Company in Tehran.

The study enjoyed a cross-section-descriptive design which involved 350 employees of selected stations of Metro Operation Company in Tehran. Stratified random sampling method was employed in this study. The data are collected by two researcher-built questionnaires of social justice and organizational citizenship behavior of "Mourman and Blacklee".

Findings: The findings showed that among dimensions of organizational citizenship behavior, civil virtue and courtesy had the highest (3.41) and the least scores 2.91, respectively. Generally, there was a significant association between justice and five dimensions of organizational citizenship behavior (i.e., civic virtue, altruism, courtesy, sportsmanship, and conscientiousness).

Regarding the relationship between justice and citizenship behavior and its association with the fulfillment of the organizational goals, it is better to think about the solutions of implementing justice in organization to achieve OCB.
\end{abstract}

Keywords: Metro Operation Company in Tehran, distributive justice, procedural justice, interactional justice, organizational citizenship behavior

\section{Introduction}

Discussion of justice and investigation of its form and nature date back to the creation of human being. It is one of the most controversial concepts in the present era. Thus, evaluation of effective factors in relation to the perception of justice and equality by the people in society namely in organizations can have crucial effect on prosperity of society in from each aspect. According to various studies regarding justice, many theorists including Aristotle, Plato, Kant, and Rawls have presented many theories in this regard the first definitions regarding justice are Plato and Aristotle's definitions (Mohammad et al., 2014). In most schools, the concept of justice is one of the fundamental principles with various definitions and perceptions.

The organizations are social systems and their sustainability depends upon the strong relation among the components and constituents. Establishment of justice can lead to coherence among these components. Indeed, it can be said that justice plays the role of coherence in organization (Marami, 2000).

Today, the world is a big organization and human relations in this world are interrelated, therefore the problems of a society in the global big community can affect other members. Thus, the concept of justice is applied in various types in organizations and institutions as justice in organizations (organizational justice), justice in legal system (judiciary justice), etc. However, in summary, all human communities require the spread of justice throughout the entire society. Thereafter, the investigation of this issue in service organizations as passenger companies including Metro in terms of providing service to a big society of citizens is of great importance.

Now, Metro Operation Company in Tehran gives services, daily, to more than 2 million people directly. While, 
indirectly, these services are offered to more than 5 Million people. Thus, investigating the relation between health and job satisfaction of employees of this company and the health of major population of citizens, and in turn the relationship between health of citizens and all aspects of social life in Tehran seem necessary. This investigation will necessarily include dealing with organizational and social behavior of the people in the society.

In line with the developments in technology and significance of human resources in 1990s, the justice researches began to investigate about the issues in relation with distributional justice, interactional justice, and procedural justice as the constituent dimensions of social justice. The following section provides a brief overview of each of these dimensions.

\subsection{Distributive Justice}

Distributive justice states the distribution of the costs and benefits among the people in the society. In other words, distributive justice emphasizes that the social rewards should be distributed among all to have fair social relations and to establish a justice-based society. Distributional justice has one of the four following forms in the writings of philosophers and theorists qualification-based distribution, fairness-based distribution, need-based distribution, and equality-based distribution (Mohammad et al., 2015).

\subsection{Procedural Justice}

In two recent decades, various studies have been conducted issuing procedural justice. This new theory eliminate the initial focus on equality and distribution but provides a new attitude on fairness and justice. Greenberg and Folger (1985) defined procedural justice as perceived fairness regarding applied procedures in taking decisions.

The initial focus of procedural justice in organizational behavior and management of human resources is the application of procedures to eliminate the challenges at work place. Thus, researchers mostly consider procedural justice regarding variety of issues related to work place such as personnel selection, reward allocation, procedures of performance evaluation, order delivery, reward systems, and participative decision making system. Thereafter, procedural justice is of great importance as a standard for managing decision making.

\subsection{Interactional Justice}

Majority of researches regarding theoretical reasoning of fairness in organizations are dedicated to procedural and interactional justice. Over the past decades, theorists made a distinction between procedural justice (which refer to the bureaucratic systems that take decisions about people) and interactional justice (quality and individual interactions among people who are communicating). The concern regarding interpersonal fairness indicates a set of issues that can be dealt under interactional justice. By interactional justice, it is raised that people can be sensitive to the quality of interpersonal behavior that they receive during organizational procedures. For example, how a manager can distribute bad news regarding new organization policy with much effect on the employees' perception of justice as the nature of news and perceived fairness of approved policies (Alavi \& Shams, 2007).

Thus, justice perception of citizens as main members of the organizations and institutions is of great importance as it can affect one's behavior, performance, and satisfaction.

On the other hand, OCB is the effort of organization members, and although it is not directly associated with job duties, it leads to the development and improvement of organization goals (Chegini, 2009). The studies of (Podsakoff, 2009) showed that almost there were 30 types of OCB that overlapped each other. According to (Organ, 1989) OCB has some dimensions as civic virtue, altruism, courtesy, sportsmanship, and conscientiousness (Raminmehr et al., 2010).

One of the most important features of the organizations that are able to work under various conditions is having people who participate in successful changes occurring in the organization beyond the formal requirements of the job. These extra-role behaviors that can be vital for the survival of organization are called OCBs. OCB is referred to the set of behaviors beyond the formal duty of people in organization (Kinicki, 2008). These behaviors are voluntary personal behaviors that are not identified directly and explicitly via formal rewarding systems but increase the effectiveness of organizational activities (Organ, 1988). The term OCB was, for the first time, raised by Organ and Bateman (Bateman \& Organ, 1983).

\subsection{Civic Virtue, Conscientiousness, and Altruism are Active and Positive Components}

Civic virtue is considering participation in organizational life. For example, presence in extracurricular activitieswhen the presence is not necessary-, supporting the development and changes presented by managers of organization, tendency to studding books and journals and increasing public information, and helping to install posters and leave notification massages in the organization to make others informed. Thus, studies believes that a 
good citizen not only should be aware of updates in the organization, but also should give opinions about them and have active participation in solving problems (Organ, 1988).

Conscientiousness is another extra-role behavior determined by the organization at work place (e.g., working after working hours to increase profits). Also, Organ believes that those with high OCB continue their work even under difficult conditions and disease.

Altruism refers to the useful and effective behaviors as intimacy, empathy among the co-workers, and direct or indirect help to the employees with work problems. Some of OCB theorists including Podsakoff, considering altruism and conscientiousness in class, refer to them as "useful behaviors".

Sportsmanship and courtesy are the components active in preventing damage to organization. Sportsmanship is the tendency to tolerate unavoidable disturbance and work preferences without any complaint. Courtesy is regarding the impact of one's on others. After mentioning these dimensions, Organ refers to the fact that it is not necessary for these five dimensions of OCB to occur at the same time (Castro, 2004).

According, OCB is affected by many variables including justice and employees' perception of justice which are of great importance in society and particularly in organizations.

\section{Method}

This study employed descriptive-analytic, quantitative, and cross sectional design. The study population included all working employees in train operator job groups, passenger services, Maintenance Operators, Command Center Operator, and employees of Metro Operation Company. Of about 8000 people, 350 were selected by stratified random sampling method. Among the selected individuals, 312 answered the distributed questionnaires.

The present study issued the general concept of justice; however, in some parts, various forms as social and organizational justice are used. To evaluate justice, the study made use of organizational justice questionnaire including distributive justice (which was applied as the main component of social justice), procedural justice, and interactional justice (which affects justice perception).

To measure citizenship behavior from the view point of (Podsakoff et al., 2009) the researchers distributed another questionnaire dealing with five components including altruism, sportsmanship, civic virtue, conscientiousness, and courtesy. Validity and reliability of both questionnaires were confirmed.

To measure the opinions of participants, the study employed (strongly agree, agree, a little agree, a little disagree, disagree, and strongly disagree) and scores ranged from 0 to5. The questionnaires were collected and the extracted information was analyzed by. In this study, social justice and its dimension (organizational justice) were considered as independent variables and OCB and its dimensions were considered as dependent variables. Pearson correlation coefficient was computed to assess the relationship between the variables.

\section{Findings}

Table 1. The means of OCB and its dimensions in studied units of Metro Operation Company

\begin{tabular}{lllllll}
\hline Units & $\begin{array}{l}\text { Citizenship } \\
\text { behavior }\end{array}$ & $\begin{array}{l}\text { Civic } \\
\text { virtue }\end{array}$ & $\begin{array}{l}\text { Conscientiou } \\
\text { sness }\end{array}$ & Courtesy & Sportsmanship & Altruism \\
\hline $\begin{array}{l}\text { Metro } \\
\text { Operation }\end{array}$ & $3 / 42$ & $3 / 46$ & $3 / 34$ & $3 / 01$ & $50 / 3$ & $70 / 3$ \\
$\begin{array}{l}\text { Command } \\
\text { Center }\end{array}$ & $2 / 97$ & $3 / 04$ & $2 / 89$ & $2 / 69$ & $10 / 3$ & $10 / 3$ \\
$\begin{array}{l}\text { Operator } \\
\text { Passenger }\end{array}$ & $3 / 27$ & $3 / 39$ & $3 / 22$ & $89 / 2$ & $25 / 3$ & $54 / 3$ \\
$\begin{array}{l}\text { services } \\
\text { train, }\end{array}$ & & $3 / 98$ & $3 / 71$ & $31 / 3$ & $72 / 3$ & $64 / 3$ \\
$\begin{array}{l}\text { Passenger } \\
\text { services }\end{array}$ & $3 / 64$ & $3 / 41$ & $3 / 32$ & $91 / 2$ & $32 / 3$ & $42 / 3$ \\
Employees & $3 / 28$ & & & & \\
\hline
\end{tabular}


As shown in Table 1, altruism and civic virtue have the highest scores and courtesy has the lowest score in selected units. Among the selected units, maintenance unit had the highest mean score in each of OCB dimensions except for altruism, and command center unit had the lowest score in all dimensions. Thus, it can be concluded that in maintenance units, the highest OCB and in command center, the lowest OCB were observed.

Table 2. The means of justice dimensions in studied units of Metro Operation Company

\begin{tabular}{llllll}
\hline & $\begin{array}{l}\text { Citizenship } \\
\text { behavior }\end{array}$ & Train services & $\begin{array}{l}\text { Command } \\
\text { Center Operator }\end{array}$ & $\begin{array}{l}\text { Passenger } \\
\text { services }\end{array}$ & $\begin{array}{l}\text { Metro } \\
\text { Operation }\end{array}$ \\
\hline Interactional justice & $3 / 47$ & $3 / 77$ & $3 / 05$ & $3 / 63$ & $3 / 84$ \\
Procedural justice & $2 / 98$ & $3 / 56$ & $2 / 46$ & $3 / 06$ & $3 / 24$ \\
Distributive justice & $2 / 23$ & $3 / 20$ & $1 / 71$ & $2 / 23$ & $2 / 02$ \\
Organizational justice & $2 / 93$ & $3 / 53$ & $2 / 45$ & $3 / 01$ & $3 / 03$ \\
\hline
\end{tabular}

As shown in Table 2, interactional justice had the highest score and distributive justice had the lowest score in selected units. Regarding the dimensions of the organizational justice, maintenance unit received the highest mean score and command center unit received the lowest mean score in all justice dimensions. Thus, it can be concluded that the highest justice perception was observed in maintenance unit.

Table 3. The correlation between justice dimensions and various OCB dimensions in studied units of Metro Operation Company

\begin{tabular}{|c|c|c|c|c|c|c|c|c|c|c|}
\hline & \multicolumn{2}{|c|}{ All Units } & \multicolumn{2}{|c|}{$\begin{array}{l}\text { Passenger } \\
\text { services }\end{array}$} & \multicolumn{2}{|c|}{ Train services } & \multicolumn{2}{|c|}{$\begin{array}{l}\text { Command } \\
\text { Center } \\
\text { Operator }\end{array}$} & \multicolumn{2}{|c|}{$\begin{array}{l}\text { Metro } \\
\text { Operation }\end{array}$} \\
\hline & $\mathrm{p}$ & $\mathrm{r}$ & $\mathrm{p}$ & $\mathrm{r}$ & $\mathrm{p}$ & $\mathrm{r}$ & $\mathrm{p}$ & $\mathrm{r}$ & $\mathrm{p}$ & $\mathrm{r}$ \\
\hline Sportsmanship &.$/ 000$ &.$/ 59$ &.$/ 000$ &.$/ 79$ &.$/ 000$ &.$/ 64$ & $000 . /$ &.$/ 68$ & .006 &.$/ 40$ \\
\hline Courtesy &.$/ 000$ &.$/ 61$ &.$/ 000$ &.$/ 63$ &.$/ 000$ &.$/ 59$ & $000 . /$ &.$/ 64$ &.$/ 000$ &.$/ 63$ \\
\hline Altruism &.$/ 000$ &.$/ 67$ &.$/ 000$ &.$/ 79$ &.$/ 000$ &.$/ 67$ & $000 . /$ &.$/ 62$ &.$/ 001$ &.$/ 49$ \\
\hline Courtesy &.$/ 000$ &.$/ 71$ &.$/ 000$ &.$/ 85$ &.$/ 000$ &.$/ 62$ & $000 . /$ &.$/ 60$ &.$/ 000$ &.$/ 73$ \\
\hline Civic virtue &.$/ 000$ &.$/ 66$ &.$/ 000$ &.$/ 69$ &.$/ 000$ &.$/ 62$ & $000 . /$ &.$/ 68$ &.$/ 001$ &.$/ 46$ \\
\hline $\begin{array}{l}\text { Citizenship } \\
\text { behavior }\end{array}$ & /000 & .82 &.$/ 000$ &.$/ 88$ & /000 &.$/ 75$ & $000 . /$ &.$/ 78$ &.$/ 000$ & ./77 \\
\hline
\end{tabular}

As shown in Table 3, there is a significant relation between organizational justice and OCB in the entire studied units. The highest and the lowest correlations were observed in passenger service unit and in maintenance unit, respectively. There is a direct correlation between organizational justice and conscientiousness in each of studied units; in passenger services unit this relation is stronger than the relation in other units. There is a direct correlation between organizational justice and courtesy in each of studied units. This was stronger in command center unit than other units. There is a direct correlation between organizational justice and altruism in each of studied units; this correlation is stronger in passenger service unit than other units. There is a direct correlation between organizational justice and civic virtue; this correlation is stronger in passenger services unit than other units. 


\section{Discussion}

According to the obtained results, justice makes people show affective and committed behavior in reaction. Indeed, the result of such interactions is stability of collective identity which is called "organizational commitment" (i.e., commitment of members to system) in systematic approach. If human being is considered as a partial intelligent factor of a system, in case of any justice in the system and the increase of systematic commitment to system together with the efforts made by its members, a peaceful relation will be established in the system (Poursaeed, 2005).

The results of the present study showed that dimensions of justice have positive and significant association with all dimensions of OCB in studied units of Operation Company. The results are consistent with the results of the studies conducted by Mardani Hamule (2008), and Nami (2006). As mentioned, interactional justice had the highest score and distributive justice had the lowest score in studied units of Operation Company. Also, the score of interactive justice in studied units indicates relative satisfaction of participants regarding the interaction with relevant authorities. Moreover, the score of distributive justice in studied units shows that employees are not satisfied with the distribution of benefits and rewards. It is possibly due to the equality of reward distribution among the line and staff personnel, since line personnel have high expectations which can lead to dissatisfaction.

The findings indicated that organizational justice is the predictive variable of most of organizational variables. In line with this finding, previous studies revealed that organizational justice has significant association with job performance (Bruker, 1996), trust to supervisors (Bace \& Shapiro, 1897), organizational commitment (Qafuri, 2010), health of employees and reduction of work absences (Warner, 2005), customer satisfaction (ELvano, 2001), and managers' commitment (Teo et al., 2001).

Citizenship behavior is the effort of organization members. Although, it is not directly associated with job duties, it can lead to the development of organizational goals (Chegini, 2009). Thus, achieving organizational goals is facilitated by the performance of employees (Shekarkan, 2009). Among OCB dimensions, civic virtue had the highest score (3.41) and courtesy had the lowest score (2.91) in the studied hospitals. The high score of civic virtue in various units shows the tendency of employees to participate in and take responsibility of extracurricular activities of Operation Company. On the other hand, the courtesy score shows that there is no relative satisfaction regarding the behavior of people with co-workers and supervisors of units. However, in the study conducted by (Yaghubi et al., 2009), citizenship activity had the highest score. The previous studies showed that OCB can be affected by many variables (Kia, 2005).

Also, the importance of organizational justice suggests that the potential source of dissatisfaction occurs when employees feel unequal. In the study the positive relation between organizational justice and OCB was proved (Dargahi, 2012). The evaluations regarding the relationship between the quality of relation and equality based on perceived model and social interaction with citizenship behavior showed that justice perception was a factor affecting OCB (Watt \& Shaffer, 2004). The mentioned results are consistent with the results of the present study (Mardani Hamale, 2009) showed that there was a stronger relation between organization justice and courtesy compared to other citizenship dimensions; however, the relation between organizational justice and sportsmanship was weaker than its relation with other dimensions of citizenship behavior (Alavi \& Shams, 2007) Some studies showed that there was a strong relation to citizenship behavior between justice perception and altruism (Dargahi, 2012). However, in this study, there was a stronger relationship between justice and sportsmanship compared to other OCB dimensions, and altruism had the second rank regarding the correlation with justice. This relation shows that in case of justice perception, employees show sportsmanship behavior which prevents complaining at work place.

On the other hand, the study by Naami and Shokrkon (2006) showed that organizational justice and had significantly positive correlation with OCB, conscientiousness, courtesy, sportsmanship, and civic virtue.

In this study, the relationship between organizational justices with courtesy was stronger than its relation with other OCB dimensions and the relationship between justice and sportsmanship was weaker than its relation with other OCB dimensions. This indicates the consistency of the results of the present study with the results of Hamale's study. In the present study, sportsmanship had strong relation with justice compared to other OCB dimensions and courtesy had the lowest correlation with organizational justice. The differences in environment, culture, and work conditions in this study would be the reason for the conflicting results.

Some studies (Ganjinia et al., 2011) showed that perception of distributive justice could explain OCB. Perception of distributive justice at confidence interval of $95 \%$ had no significant impact on OCB but other dimensions of organizational justice perception (i.e., interpersonal, informative, and procedural) were effective on OCB as was shown in similar studies. 


\section{Conclusion}

The current study shows there is a strong relationship among citizenship behavior with justice perception and equity in organizations. With regard to providing service to the public, in relation with altruism and reverence has a great significance, from the other hand, Variety of job duties in Metro operation company and the multiplicity of staff forces (most of them are extra) are the reasons for the equal scores of staff and line forces while line forces are permanently involved in service providing and don't have good work places. This was considerable in verbal statements of employees. Regarding the sociability of human beings and their altruism behaviors, this study concluded that the increase in justice perception by employees improves citizenship behaviors in employees and leads to the provision of good services in the society.

\section{References}

Alavi, A., \& Shams, A. (2007). Analytical philosophy of justice and fairness in Iran health system equity. In Conference of Justice in Health Care. Isfahan: Isfahan University of Medical Sciences.

Bace, R. J., \& Shapiro, D. L. (1987). Interactional fairness judgments: The influence of causal accounts. Social Justice Research, 1(2), 199-218.

Brockner, J., Wiesenfeld, B. M., \& Martin, C. L. (1995). Decision frame, procedural justice, and survivors' reactions to job layoffs. Organizational Behavior and Human Decision Processes, 63, $59-68$.

Castro, C. B., Armario, E. M., \& Ruiz, D. M. (2004). The influence of employee organizational citizenship behavior on customer loyalty. International Journal of Service Industry Management, 15(1), 27-53.

Chegini M. G. (2009). The relationship between organizational justice and organizational citizenship behavior. American Journal of Economics and Business Administration, 1(2), 173-176.

Dargahi, H., Alirezaie, S., \& Shaham, G. (2012). Organizational citizenship behavior among Iranian nurses. Iranian Journal of Public Health, 41(5), 85-90.

Elovainio, M., Kivimaki, M., Steen, N., \& Vahtera, J. J. (2004). Decision latitude, organizational justice and health: Multilevel covariance structure analysis. Social Science and Medicine, 59(9), 1659-1669.

Ghafuri, M. R., Safadorani, V., \& Golparvar, M. (2010). Simple and multiple relationships of perceived organizational justice and organizational commitment in central municipals of Isfahan. Psychology Studies, 5(4), 129-149 [Article in Persian].

Psychol Bull. (1996). Interactive effects outcomes and procedure. Journal of Strategic Studies, 120(2), 189-208.

Kia, M. (2005). Theories of management and organization models. In Tehran: Center for Public Management Education Publication (pp. 17-18) [Book in Persian].

Kreitner, Robert., \& Kinicki. (2008). International student. In Angelo Organizational behavior (8th ed.). Boston: McGraw-Hill Irwin.

Marami, A. R. (2000). The comparison of justice conception (view of Motahari, Shariati, and Sayed Ghotb). In Tehran: Markaze Asnade Enghlabe Eslami Publication (pp. 187-197) [Book in Persian].

Mardani Hamule, M., \& Shahraky Vahed, A. (2009). The Assessment of Relationship between Mental Health and Quality of life in Cancer Patients. Scientific Journal of Hamadan University of Medical Sciences, 16(2), 33-38.

Markaze Asnade Enghlabe Eslami Publication. (2000). (pp. 187-197) [Book in Persian].

Mohammad, H., Qurban, G., \& Khearidin, E. (2015). Amount of sense of social justice and social satisfaction (in high educational students in Dushanbe, Tajikistan). Journal of Economics and Engineerin, 3817. http://dx.doi.org/10.7813/jee.2015/6-1

Naami, A. Z., \& Shokrkon, H. (2006). A study between organizational justice and organizational citizenship behaviour in industrial organization in Ahvaz. Journal of Education and Psychology, 13(1), 79-92 [Article in Persian].

Organ, D. W. (1988). Organizational citizenship behavior: The good soldier syndrome. USA: D. C. Heath and Company.

Organizational justice and organizational commitment in central municipals of Isfahan. (2010). Psychology Studies, 5(4), 129-149 [Article in Persian]. 
Podsakoff, N. P., Whiting, S. W., \& Blume, B. D. (2009). Individual-Individual and organizational-level consequences of organizational citizenship behaviors a meta-analysis. Journal of Applied Psychology, 94(1), 122-141. http://dx.doi.org/10.1037/a0013079

Poursaeed, F. (n.d.). Inclusive and sustainable Guidelines social justice in 1404 Hijri Shamsi.

Raminmehr, H., Hadizadeh Moghadam, A., \& Ahmadi, I. (2010). Study the relationship between organizational justice perception and organizational citizenship behavior. Journal of Management Development, 1(2), 65-89 [Article in Persian].

Shekarkan, H., Naami, A. Z., Nissi, A. K., \& Mehrabizade Honarmand, M. (2009). Survey of the relationship between job satisfaction and organizational citizenship behavior and job performance of employees in manufacturing in Ahvaz. Journal of Education and Psychology, 8(3-4), 1-22 [Article in Persian].

Teo, T. S. H., \& Lim, V. K. G. (2001). The effect of perceived justice on satisfaction and behavior intentions: The case of computer purchase. Journal of Retail \& Distribution of Management, 29(2), 109-124.

Warner, J. C., Raynolds, J., \& Roman, P. (2005). Organizational justice and job satisfaction: A test of three competing models. Social Justice Research, 18(4), 391-409.

Wat, D., \& Shaffer, M. A. (2004). Equity and relationship quality influences on organizational citizenship behaviors: The mediating role of trust in the supervisor and empowerment. Personal Review, 34(4), 406-422.

Yaghobi, M., Yarmohammadian, M. H., Raeesi, A. R., Saghaiannezhad Esfahani, S., \& Javadi, M. (2009). The study of relationship between the organizational justice and organizational citizenship behavior among medical records in hospitals of IUMS. Health Information Management Journal, 7(Special Issue), 506-515 [Article in Persian].

\section{Copyrights}

Copyright for this article is retained by the author(s), with first publication rights granted to the journal.

This is an open-access article distributed under the terms and conditions of the Creative Commons Attribution license (http://creativecommons.org/licenses/by/3.0/). 